\title{
Results From Brazil's 2016 Report Card on Physical Activity for Children and Youth
}

\author{
Nelson Nardo Jr., Diego Augusto Santos Silva, Gerson Luis de Moraes Ferrari, Edio Luiz Petroski, \\ Ricardo Lucas Pacheco, Priscila Custódio Martins, Luis Carlos Oliveira, Timóteo Leandro Araújo, \\ Anselmo Alexandre Mendes, Samara Pereira Brito Lazarin, Tamires Leal Cordeiro dos Santos, \\ and Victor Matsudo
}

\begin{abstract}
Background: Very few studies have comprehensively analyzed the physical activity of children and adolescents in Brazil. The purpose of this article is to show the methodology and summarize findings from the first Brazilian Report Card on Physical Activity for Children and Youth. Methods: Three Brazilian research institutions coordinated the activities to develop the Brazilian 2016 Report Card. The data available were collected independently and then synthesized by the Research Work Group using the grade system developed for the First Global Matrix released in 2014, which included 9 indicators of physical activity. Where possible, grades were assigned based on the percentage of children and youth meeting each indicator: $A$ is $81 \%$ to $100 \%$; $B$ is $61 \%$ to $80 \%$; $C$ is $41 \%$ to $60 \%$; $D$ is $21 \%$ to $40 \%$; $F$ is $0 \%$ to $20 \%$; INC is incomplete data. Results: Among the 9 indicators, only 5 had sufficient data for grading. Overall Physical Activity received a $C$-grade, Active Transportation received a $C+$ grade, Sedentary Behavior received a $D+$ grade, and Government Strategies and Investments received a $D$ grade. Conclusion: The low grades observed highlight the need for continued efforts aimed at improving physical activity in Brazilian children.
\end{abstract}

Keywords: sedentary behavior, active transport

Physical inactivity is associated with major noncommunicable diseases and all-cause mortality. ${ }^{1,2}$ It is estimated that $31 \%$ of the global population does not meet current physical activity (PA) recommendations. ${ }^{3}$ The burden of disease attributable to inactivity was recently estimated to be responsible for $6 \%$ to $9 \%$ of the total deaths worldwide. ${ }^{2}$

PA is essential for overall health at every age. ${ }^{1}$ Public health guidelines recommend that children and adolescents engage in $\geq 60$ minutes of moderate-to-vigorous physical activity (MVPA) daily; ${ }^{1}$ however, there is limited evidence on PA levels of children and youth and less information about community-based practices or governmental programs for the promotion of PA in Brazil.

The 2016 Brazilian Physical Activity Report Card is a maiden effort to establish national baseline data on PA indicators. The evidence presented is intended to inform future research and interventions toward promoting PA among Brazilian children and adolescents. The 2016 Brazilian Report Card is the first report card completed in Brazil. The report card was inspired by the Active Healthy Kids Global Alliance, ${ }^{4}$ which has been reporting on PA and PA-enabling environments of children and youth.

The report card provides potentially important information on PA indicators, policies and programs for the Brazilian community

Nardo, Mendes, Lazarin, and dos Santos are with the Dept of Physical Education, Health Sciences Center, State University of Maringá, Maringá, Brazil. Silva, Petroski, Pacheco, and Martins are with the Sports Center, Center for Research in Human Performance and Kinanthropometry, Federal University of Santa Catarina, Florianópolis, Brazil. Ferrari, Oliveira, Araújo, and Matsudo are with the Center for Physical Fitness Laboratory Studies of São Caetano do Sul, São Paulo, Brazil. Ferrari (gersonferrari08@yahoo. com.br) is corresponding author. and stakeholders, and for the Latin American region in general. The report card is a useful tool that can improve the effectiveness of advocacy for PA promotion..$^{5}$

The objective of this manuscript is present the methodology and summarize findings of the first Brazilian Physical Activity Report Card for Children and Youth. Data from a number of national and state-based surveys were synthesized to assign the grades to each of the Report Card indicators.

\section{Methods}

The 2016 Brazilian Report Card was coordinated, developed, and produced by a group of researchers from 3 institutions with experience in child and adolescent PA and health: the Center for Physical Fitness Laboratory Studies of São Caetano do Sul (CELAFISCS); the Department of Physical Education, Health Sciences Center at the State University of Maringa; and the Sports Center-Center for Research in Human Performance and Kinanthropometry at the Federal University of Santa Catarina. The Brazilian Report Card was based on the structure and indicators of the Canadian Report Card. ${ }^{4}$

A Research Work Group (RSW) of established experts and stakeholders from South and Southeast of Brazil was convened to evaluate the aggregated evidence and assign grades for each PA indicator. ${ }^{4}$ The experts and stakeholders were selected based on experience in research about physical activity in children and adolescents. The meetings were online and face to face. The responsibilities of the RWG included 1) to decide upon how each indicator would be operationalized; 2) to determine which, if any, extra indicators would be included along with the 9 core indicators of the Report Card; 3) to assess what data sources could and should be assessed to inform the grades assigned; and 4) to meet and evaluate the collected and synthesized data to make informed 
decisions on the grades to be assigned to each indicator. Relevant data sources on the core indicators for Brazilian children and youth aged 5 to 17 years were searched for and analyzed. All published, peer-reviewed studies were included if they reported use of subjective or objective measures PA in population-based samples of children and adolescents.

Consensus was achieved on final grade assignments for each indicator. The Brazilian Report Card presents 9 indicators related to PA in Brazilian children and youth: 1) Overall Physical Activity; 2) Organized Sport Participation; 3) Active Play; 4) Active Transportation; 5) Sedentary Behavior; 6) Family and Peers; 7) School; 8) Community and the Built Environment; and 9) Government Strategies and Investments. The RWG assigned letter grades by using a grading scheme where letter grades were based on the proportion of children achieving the benchmark for each indicator (Table 1). ${ }^{4}$

Several sources of national data were used to inform the grades of each PA indicator, including the 2009 and 2012 National Survey of School Health (PeNSE_-Pesquisa Nacional de Saúde do Escolar $)^{6,7}$ and 2 systematic reviews about PA and sedentary behavior in Brazilian children and adolescents. ${ }^{8,9}$ PeNSE is the main source of information on risk and protective factors for health in adolescents from public and private schools in Brazil. PeNSE included a representative sample of students from the final (ninth) year of elementary education, selected on the basis of a complex multistage, stratified, clustered probability design. ${ }^{6,7}$

The researchers worked collaboratively to evaluate available data synthesized by the Scientific Officer. Based on this discourse, and once consensus had been reached, grades were assigned for each indicator. ${ }^{4}$

\section{Results and Discussion}

Table 2 summarizes the grades assigned by the group of researchers for each indicator. An explanation is also provided below. Figure 1 shows the cover for the report card.

\section{Overall Physical Activity: C-}

No recommendations on the minimum amount of PA exist in Brazil. In other countries, this recommendation is well established..$^{3}$ The guidelines state that children aged 5 to 17 years old should accumulate at least 60 minutes of MVPA on a daily basis. ${ }^{1}$ We decided to use a minimum of $300 \mathrm{~min} /$ week of MVPA. Overall PA levels were assigned a $C$-grade as it was estimated that $41.7 \%$ of $6-$ to 19-year-olds Brazilian children and youth meet the PA guidelines everyday (ie, $\geq 300$ minutes/week). Data were analyzed from one systematic review of Brazilian studies. ${ }^{9}$ National data in Brazil (National Survey of School Health-PeNSE 2012) also informed the grade. ${ }^{7}$ Sex differences were also evident in the data with boys being more active than girls. ${ }^{4}$ For this report card was considered 19 original studies surveyed in the systematic review. ${ }^{9}$ These studies investigated physical activity by questionnaire and used the cutoff point of $300 \mathrm{~min} /$ week of MVPA. In PeNSE, ${ }^{7}$ overall PA is investigated by self-reported questionnaire and used cutoff point of 300 min/week of MVPA (Table 3).

In terms of the Overall PA levels, several regional differences within Brazil were identified from the PeNSE data. ${ }^{7}$ The region with the largest proportion of children meeting government PA recommendations was in the South of Brazil (36.3\%), whereas the

\begin{tabular}{ll}
$\begin{array}{l}\text { Table } 1 \\
\text { and Youth }\end{array}$ & Grading Framework for the 2016 Brazilian Report Card on Physical Activity for Children \\
\hline Grade & Interpretation \\
\hline$A$ & We are succeeding with a large majority of children and youth $(\geq 80 \%)$ \\
$B$ & We are succeeding with well over half of children and youth $(60 \%-79 \%)$ \\
$C$ & We are succeeding with about half of children and youth $(40 \%-59 \%)$ \\
$D$ & We are succeeding with less than half but some children and youth $(20 \%-39 \%)$ \\
$F$ & We are succeeding with very few children and youth $(<20 \%)$ \\
\hline
\end{tabular}

Table 2 Grades for the 2016 Brazilian Report Card on Physical Activity for Children and Youth

\begin{tabular}{lc}
\hline Indicator & Grade \\
\hline 1. Overall physical activity & $C$ - \\
2. Organized sport participation & $I N C$ \\
3. Active play & $I N C$ \\
4. Active transportation & $C+$ \\
5. Sedentary behavior (TV viewing) & $D+$ \\
6. Family and peers & $C+$ \\
7. School & $I N C$ \\
8. Community and the built environment & $I N C$ \\
9. Government strategies and investments & $D$ \\
\hline
\end{tabular}

Note. INC is incomplete data. 


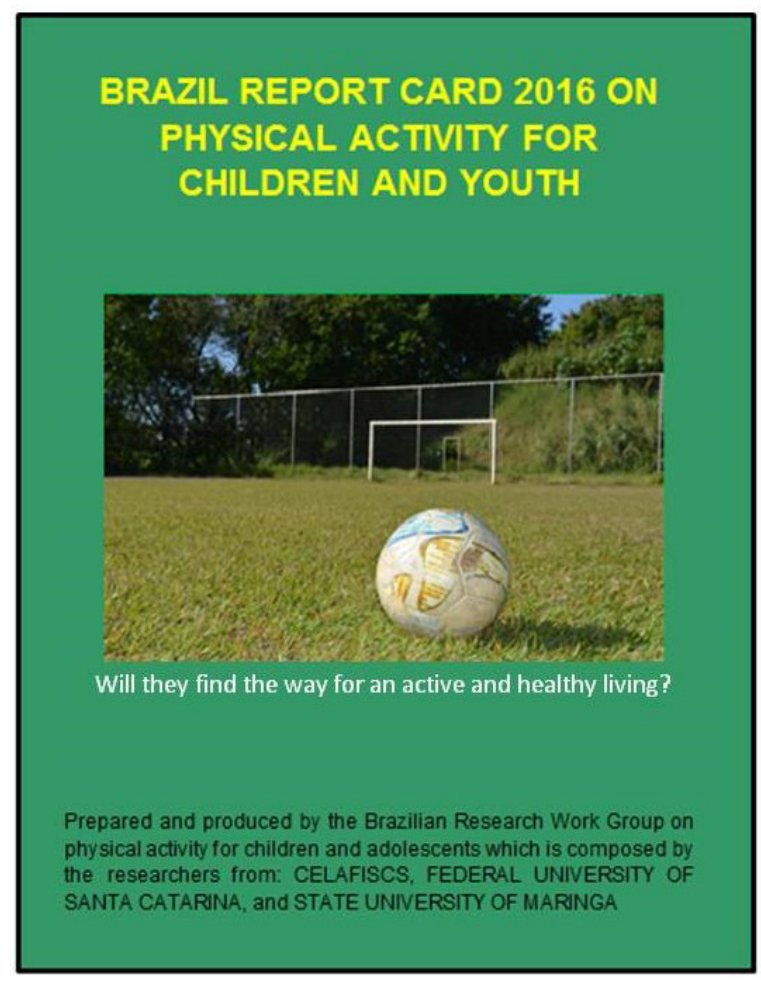

Figure 1 - Front cover of Brazil's 2016 Report Card on Physical Activity for Children and Youth.

region with the lowest percentage achieving the government target was the Northeast $(25.2 \%){ }^{7}$

\section{Organized Sport Participation: INC}

In Brazil there are several programs that provide opportunities for children and youth participation in organized sports. However, no data on actual participation in organized sports were available. Therefore, the grade assigned was incomplete (INC). Further research is required if we want to better understand how much sport per week is desirable for health benefits as well as to tease out participation in sport and PA clubs (ie, to obtain a better understanding of the type of organized activities that children in Brazil are engaged in).

\section{Active Play: INC}

This indicator was lacking in the literature and should be explored in future studies. There was a lack of data to inform the grade for this indicator. For that reason the grade $I N C$ was applied.

\section{Active Transportation: $\mathbf{C +}$}

Some active transportation studies were available. Based on one study with 1570 school children (7- to 12-years-old) from João Pessoa/PB, $70 \%$ of children used active transport to get to/from school (Grade B). ${ }^{10}$ Another study involving 4207 teenagers (14to 19 -years-old) revealed that $43 \%$ of teenagers used active rather than motorized transport (Grade $C$ ). ${ }^{11}$ Finally, a study with 1442 school children (7- to 12-years-old) showed that $58 \%$ used active transport to go to school (Grade $C$ ). ${ }^{12}$ Based on these findings, the grade for this indicator was $C+$.

\section{Sedentary Behavior: D+}

In this report card, screen time (TV viewing) was considered synonymous to sedentary behavior. No recommendations on the maximum amount of sedentary time exist for Brazil. In other countries this recommendation is made. ${ }^{13,14}$ Using the target of the percentage of children and adolescents watching $\leq 2 \mathrm{hr}$ of TV/day, this indicator was graded $D$. Data were analyzed from two systematic reviews of Brazilian studies, ${ }^{8,9}$ national data (National Survey of School Health-PeNSE 2012) ${ }^{7}$ and regional data that reported on the time spent watching TV. ${ }^{15}$ In total, we analyzed data of 197,086 youth in Brazil aged 2 to 19 years. Of this sample, $23.8 \%$ watched $\leq 2$ hours of TV/day. Sedentary behaviors are distinct and independent from PA behaviors of various intensities $>1.5$ METs (ie, light, moderate, and vigorous intensity). ${ }^{14}$ Based on these results, the RWG assigned a $D+$ to the indicator. Importantly, it is possible to meet PA recommendations and still engage in high amounts of sedentary behavior. A systematic review showed that young people with sedentary risk behavior were more prone to gain weight, to be overweight or obese, and to have poor performance on physical fitness tests, higher levels of blood pressure, total cholesterol and triglycerides, higher chances of showing depressive symptoms, low self-esteem, aggressiveness, inappropriate social behaviors, and poor academic performance. ${ }^{16}$

\section{Family and Peers: $\mathbf{C +}$}

There were little data available for this indicator. One study by Fermino et $\mathrm{al}^{17}$ involving 1518 teenagers (14- to 18 -years-old) from Curitiba showed that $53 \%$ of parents support the PA of their kids, while $71 \%$ of their friends are supportive of PA participation, resulting in a average grade of $C+$.

\section{School: INC}

The school infrastructure, policies, and programs indicator was graded $I N C$ despite the evidence for Physical Education (PE) and opportunities for sports and PA in the school environment. More research conducted in Brazil on this indicator is needed. In addition, there are no assessments of the impact of policies and programs in schools. The data collected for the National Survey of School Health (PeNSE) in 2012 used a nationally representative sample of 109,104 Brazilian students from 2842 schools and showed that schools with at least one PA facility had increased odds of participation in PE (OR 1.59; 95\% CI 1.20-2.10). However, to increase leisure time PA (OR 1.14; 95\% CI 1.03-1.26) and total PA level (OR 1.15; 95\% CI 1.06-1.24), at least 4 and 2 facilities, respectively, were necessary. Extracurricular sports activities in schools were positively associated with leisure-time PA and PA level. The number of sports courts and swimming pool in a school were associated with participation in PE classes. ${ }^{18}$ The potential influence of a favorable school context on PA has been a matter of discussion in recent years. ${ }^{19-21}$ Studies conducted in Ontario (Canada); ${ }^{19}$ Minnesota, United States of America (US); ${ }^{20}$ and San Diego (US) ${ }^{21}$ consistently observed the influence of the school context on MVPA for students between the 6 th and 12th grade. The school is seen as the ideal environment for the incentive and intervention associated with PA, and PE classes seem to have a key role in this scenario. ${ }^{22}$ It is necessary that the practice of PA within the school environment be considered an important mechanism for this specific population and an inseparable part of the overall educational process, as the effective participation of adolescents in PE classes allow them to decrease exposure to health risk behaviors. ${ }^{23}$ 
Table 3 Surveys Used to Inform Each of the Grades Allocated to Each Indicator of the Report Card

\begin{tabular}{|c|c|c|c|}
\hline Survey & Representativeness & Age group & Indicator informed ${ }^{*}$ \\
\hline PeNSE, $2009^{6}$ & National & 9th grade & 1,5 \\
\hline PeNSE, $2012^{7}$ & National & 9th grade & 1,5 \\
\hline Guerra et al $2016 \dagger^{8}$ & National & $2-19$ years & 5 \\
\hline Barbosa Filho et al $2014 \dagger^{9}$ & National & $10-19$ years & 1,5 \\
\hline Silva et al $2016^{29}$ & State & 5 th-8th grade & 1 \\
\hline Fermino et al $2010^{17}$ & State & 14-18 years & 1,6 \\
\hline Matsudo et al $2016^{30}$ & State & $9-11$ years & 1 \\
\hline Cureau et al $2016^{31}$ & National & 12-17 years & 1 \\
\hline Silva et al $2007^{32}$ & State & 14-19 years & 5 \\
\hline Silva et al $2007^{10}$ & State & $7-12$ years & 4 \\
\hline Santos et al $2010^{11}$ & State & 14-19 years & 4 \\
\hline Rech et al $2013^{12}$ & State & $7-12$ years & 4 \\
\hline Tenório et al $2010^{33}$ & State & 14-19 years & 5 \\
\hline Dias et al $2014^{34}$ & State & $10-17$ years & 5 \\
\hline Copetti et al $2010^{35}$ & State & $10-19$ years & 5 \\
\hline Ceschini et al $2009^{36}$ & State & 14-19 years & 5 \\
\hline Ferreira et al $2015^{37}$ & State & 5 th-12th grade & 5 \\
\hline Ferrari et al $2015^{38}$ & State & $9-11$ years & 5 \\
\hline Ferrari et al $2015^{39}$ & State & $9-11$ years & 5 \\
\hline Bracco et al $2006^{40}$ & State & $7-10$ years & 5 \\
\hline Loch et al $2015^{41}$ & State & $12-18$ years & 6 \\
\hline Brasil $2016^{42}$ & National & $6-18$ years & 9 \\
\hline
\end{tabular}

* Number coincides with how indicators were listed in the Methods section; $\dagger$ systematic review.

\section{Community and the Built Environment: INC}

There were no qualified studies to grade and therefore this indicator was considered INC for this report card due to a lack of data.

\section{Government Strategies and Investments: D}

Interventions to increase PA have been recently implemented in Brazil. ${ }^{24,25}$ For example, the elaboration of the National Plan of Body Practices and Physical Activity (Plano Nacional de Práticas Corporais e Atividade Física) aiming at the induction of their public policies at the municipal level, as well as the implementation of the actions contained in the Growth Acceleration Program of Health 2007-2010 (Programa de Aceleração do Crescimento da Saúde) and the Multi-Year Plan of the Ministry of Health (Plano Plurianual do Ministério da Saúde), are good examples. The document aims to stimulate coordination between the sectors of Health, Education, Cities, Culture, Agricultural Development, and the Government with Nongovernment Organizations (NGOs), such as scientific institutions and the private sector, through national cooperation agreements. Their goal is to spread the topic of PA and promote the construction and implementation of projects in schools, and public recreational areas, facilitating investment in healthier urban spaces and increased access to information for healthier lifestyles in citizen's daily life. ${ }^{24}$

Implemented in 1996, the Agita São Paulo program has increased (at the state level in particular) people's knowledge regarding the biological, psychological, and social health benefits of PA and people's involvement in MVPA. ${ }^{26}$ One of the Agita São Paulo's initiatives is the Agita Galera Program, ${ }^{27}$ which aims to promote awareness and PA at school among children and youth. According to official data of the Board of Education of São Paulo (Secretaria da Educação do Estado de São Paulo), this school system is currently the largest in Brazil with 5300 schools, 230,000 teachers, 59,000 staff, and more than 4 million students. ${ }^{28}$

Considering this, it seems reasonable to state that the Government Strategies and Investments exist-and some of them are indeed well known like the Second Time Program, "Programa Segundo Tempo." However, the reach of these programs is very limited. Based on data from the Ministry of Sports called "Sistema de monitoramento e avaliação dos programas Esporte e Lazer da Cidade e Programa Segundo Tempo Do Ministério do Esporte," the main federal program was able to involve only $0.27 \%$ of the Brazilian children and adolescents. For that reason, this indicator received a grade of $D$.

The policy implications of these results leads to increased monitoring of PA programs for young people exist in Brazil. In addition to this monitoring it is necessary that these programs reach more young people in Brazil, especially those with low incomes who do not have other sports practice options and structured PA. Finally, a greater involvement of the public and private sector in the concern for the health of young people is necessary. 


\section{Strengths and Limitations}

Because of the limited data available, only 5 of the 9 indicators could be graded. Thus, conclusions and comparisons with report cards from other countries are limited. Several studies lack national representation and also present limited methodology description. Further, the PA and sedentary behavior data used in this report card were mainly self-reported, which may bias true estimates. Finally, evidence about the effectiveness of current policies and programs is lacking, which prevents conclusions on their potential to promote PA among children and youth.

\section{Conclusion}

The 2016 Brazilian Physical Activity Report Card shows that overall PA levels are low and sedentary behaviors are high among Brazilian children and youth. It also shows that PE classes must be more present in schools all around the country, which could change these results. Finally, it will be important to better study and report on the indicators whose data were insufficient to assign a grade to guide policies of health promotion.

\section{Acknowledgments}

This research was only possible because of the partnership between the three research groups and their members. The authors are grateful to the following individuals and institutions for their contributions to the 2016 Brazilian Report Card on Physical Activity for Children and Youth: Dr. Mark Tremblay, Healthy Active Living and Obesity Research Group, Children's Hospital of Eastern Ontario Research Institute, Canada. The production of the 2016 Brazilian Report Card was partially supported through the funding from the Conselho Nacional de Pesquisa (CNPq).

\section{References}

1. World Health Organization (WHO). Global Recommendations on Physical Activity for Health. Geneva: World Health Organization; 2010.

2. Lee IM, Shiroma EJ, Lobelo F, et al. Effect of physical inactivity on major non-communicable diseases worldwide: an analysis of burden of disease and life expectancy. Lancet. 2012;380(9838):219-229. PubMed doi:10.1016/S0140-6736(12)61031-9

3. Hallal PC, Andersen LB, Bull FC, et al. Global physical activity levels: surveillance progress, pitfalls, and prospects. Lancet. 2012;380(9838):247257. PubMed doi:10.1016/S0140-6736(12)60646-1

4. Colley RC, Brownrigg M, Tremblay MS. A model of knowledge translation in health: the Active Healthy Kids Canada Report Card on Physical Activity for Children and Youth. Health Promot Pract. 2012;13(3):320-330. PubMed doi:10.1177/1524839911432929

5. González SA, Sarmiento OL, Cohen DD, et al. Results from Colombia's 2014 Report Card on Physical Activity for Children and Youth. J Phys Act Health. 2014;11(Suppl 1):S33-S44. PubMed doi:10.1123/ jpah.2014-0170

6. Brazil Ministry of Health, Brazilian Institute of Geography and Statistics. 2009 National Survey of School Health. Rio de Janeiro, Brazil: Ministry of Health, Brazilian Institute of Geography and Statistics; 2009.

7. Brazil Ministry of Health, Brazilian Institute of Geography and Statistics. 2012 National Survey of School Health. Rio de Janeiro, Brazil: Author; 2013.
8. Guerra PH, Farias Júnior JC, Florindo AA. Sedentary behavior in Brazilian children and adolescents: a systematic review. Rev Saude Publica. 2016;50:9. PubMed doi:10.1590/S1518-8787.2016050006307

9. Barbosa Filho VC, de Campos W, Lopes Ada S. Epidemiology of physical inactivity, sedentary behaviors, and unhealthy eating habits among Brazilian adolescents: a systematic review. Cien Saude Colet. 2014;19(1):173-193. PubMed doi:10.1590/1413-81232014191.0446

10. Silva KS, Lopes AS, Silva FM Comportamentos sedentários associados ao excesso de peso corporal. Rev bras Educ Fís Esp. 2007;21(2):135-141.

11. Santos CM, Júnior RDSW, Barros SSH, de Farias Júnior JC, de Barros MVG. Prevalence of physical inactivity and associated factors among adolescents commuting to school. Cad Saude Publica. 2010;26(7):1419-1430. PubMed doi:10.1590/S0102311X2010000700021

12. Rech RR, Rosa CO, Avrela PR. Fatores associados ao deslocamento ativo em escolares. Rev Bras Ativ Fis e Saude. 2013;18(3):332-338.

13. American Academy of Pediatrics, Committee on Public Education. American Academy of Pediatrics: children, adolescents, and television. Pediatrics. 2001;107(2):423-426. PubMed doi:10.1542/ peds.107.2.423

14. Tremblay MS, Leblanc AG, Janssen I, et al. Canadian sedentary behaviour guidelines for children and youth. Appl Physiol Nutr Metab. 2011;36(1):59-64, 65-71. PubMed doi:10.1139/H11-012

15. Silva DA, Tremblay MS, Gonçalves EC, Silva RJ. Television time among Brazilian adolescents: correlated factors are different between boys and girls. ScientificWorldJournal. 2014;2014:794539. PubMed

16. Tremblay MS, LeBlanc AG, Kho ME, et al. Systematic review of sedentary behaviour and health indicators in school-aged children and youth. Int J Behav Nutr Phys Act. 2011;8:98. PubMed doi:10.1186/1479-5868-8-98

17. Fermino RC, Rech CR, Hino AAF, Añez CRR, Reis RS. Physical activity and associated factors in high-school adolescents in Southern Brazil. Rev Saude Publica. 2010;44(6):986-995. PubMed doi:10.1590/ S0034-89102010000600002

18. Rezende LFM, Azeredo CM, Silva KS, et al. The role of school environment in physical activity among Brazilian adolescents. PLoS One. 2015;10(6):e0131342. PubMed doi:10.1371/journal.pone.0131342

19. Hobin EP, Leatherdale ST, Manske S, Dubin JA, Elliott S, Veugelers P. A multilevel examination of gender differences in the association between features of the school environment and physical activity among a sample of grades 9 to 12 students in Ontario, Canada. BMC Public Health. 2012;12:74. PubMed doi:10.1186/1471-2458-12-74

20. Patnode CD, Lytle LA, Erickson DJ, Sirard JR, Barr-Anderson D, Story M. The relative influence of demographic, individual, social, and environmental factors on physical activity among boys and girls. Int J Behav Nutr Phys Act. 2010;7:79. PubMed doi:10.1186/14795868-7-79

21. Sallis JF, Conway TL, Prochaska JJ, McKenzie TL, Marshall SJ, Brown M. The association of school environments with youth physical activity. Am J Public Health. 2001;91(4):618-620. PubMed doi:10.2105/AJPH.91.4.618

22. Santos JS, Hardman CM, Barros SSH, Santos CFBF, Barros MVG. Association between physical activity, participation in physical education classes, and social isolation in adolescents. $J$ Pediatr (Rio J). 2015;91(6):543-550. PubMed doi:10.1016/j.jped.2015.01.008

23. Tergerson JL, King KA. Do perceived cues, benefits, and barriers to physical activity differ between male and female adolescents? J Sch Health. 2002;72(9):374-380. PubMed doi:10.1111/j.1746-1561.2002. tb03562.x 
24. Malta D, Castro A, Gosh C, et al. National policy of health promotion and the motor activity agenda in the context of the National Health System in Brazil. Epidemiol Serv Saúde. 2009;18(1):79-86.

25. Matsudo SM, Matsudo VR, Araújo TL. The Agita São Paulo Program as a model for using physical activity to promote health. Rev Panam Salud Publica. 2003;14(4):265-273. PubMed doi:10.1590/S102049892003000900007

26. Matsudo SMM, Matsudo VKR, Araújo TL, Andrade E, Oliveira L, Braggion G. Physical activity promotion: experiences and evaluation of the Agita São Paulo Program using the ecological mobile model. $J$ Phys Act Health. 2004;1:81-97. doi:10.1123/jpah.1.2.81

27. Zieff SG, Guedes CM, Wiley J. Youth knowledge of physical activity health benefits: a Brazilian case study. ScientificWorldJournal. 2006;6:1713-1721. PubMed doi:10.1100/tsw.2006.283

28. Secretaria da Educação do Estado de São Paulo. A Secretaria. http:// www.educacao.sp.gov.br/ Accessed October 25, 2016.

29. Silva LJ, Matsudo VKR, Andrade DR, et al. The prevalence of physical activity and its associated effects among students in the São Paulo public school network, Brazil. Cien Saude Colet. 2016;21(4):10951103. PubMed doi:10.1590/1413-81232015214.19792015

30. Matsudo VKR, Ferrari GLMF, Araújo TL, et al. Socioeconomic status indicators, physical activity, and overweight/obesity in Brazilian children. Rev Paul Pediatr. 2016;34(2):162-170. PubMed doi:10.1016/j. rpped.2015.04.003

31. Cureau FV, Silva TLN, Bloch KV, et al. ERICA: Inatividade física no lazer em adolescentes brasileiros. Rev Saude Publica. 2016;50(supl 1):4s. PubMed

32. Silva KSD, Lopes ADS, Silva FMD. Atividade física no deslocamento à escola e no tempo livre em crianças e adolescentes da cidade de João Pessoa, PB, Brasil. Rev Bras Ciênc Mov. 2007;15:61-70.

33. Tenório MCM, Barros MD, Tassitano RM, Bezerra J, Tenório JM, Hallal PC. Physical activity and sedentary behavior among adolescent high school students. Rev Bras Epidemiol. 2010;13(1):105-117. PubMed
34. Dias PJP, Domingos IP, Ferreira MG, Muraro AP, Sichieri R, Gonçalves-Silva RMV. Prevalence and factors associated with sedentary behavior in adolescents. Rev Saude Publica. 2014;48(2):266-274. PubMed doi:10.1590/S0034-8910.2014048004635

35. Copetti J, Neutzling MB, Silva MC. Barriers to physical activity practice in adolescents of southern Brazilian city. Rev Bras Ativ Fis e Saude. 2010;15(2):88-94.

36. Ceschini FL, Andrade DR, Oliveira LC, Araujo JF Jr, Matsudo VK. Prevalence of physical inactivity and associated factors among high school students from state's public schools. J Pediatr (Rio J). 2009;85(4):301-306. PubMed doi:10.1590/S002175572009000400006

37. Ferreira RW, Rombaldi AJ, Ricardo LIC, Hallal PC, Azevedo MR. Prevalence of sedentary behavior and its correlates among primary and secondary school students. Rev Paul Pediatr. 2016;34(1):56-63. PubMed doi:10.1016/j.rpped.2015.06.005

38. Ferrari GL, Oliveira LC, Araujo TL, et al. Moderate-to-vigorous physical activity and sedentary behavior: independent associations with body composition variables in Brazilian children. Pediatr Exerc Sci. 2015;27:380-389. PubMed doi:10.1123/pes.2014-0150

39. Ferrari GL, Araujo TL, Oliveira L, et al. Association between television viewing and physical activity in 10-year old Brazilian children. J Phys Act Health. 2015;12:1401-1408. PubMed

40. Bracco MM, Colugnati FA, Pratt M, Taddei JA. Multivariate hierarchical model for physical inactivity among public school children. $J$ Pediatr (Rio J). 2006;82(4):302-307. PubMed

41. Loch MR, Porpeta RH, Brunetto BC. Relationship between the practice of physical activity during leisure time of parents and their children. Rev Bras Ciên Esporte. 2015;37(2):29-34. doi:10.1016/j. rbce.2013.09.001

42. Brasil. Ministério dos Esportes. Sistema de monitoramento e avaliação dos programas esporte e lazer da cidade e Segundo Tempo Ministério do Esporte. http://portal.esporte.gov.br/snee/segundotempo/avaliacao. jsp. Accessed June 15, 2016. 